\title{
FOREWORD
}

\section{CHALLENGES IN RECRUITMENT AND RETENTION: IS THERE A SOLUTION?}

The recruitment and retention of well-qualified military personnel are essential for any armed forces. This is even more true because most armed forces in Europe have shifted from a conscript-based to an all-volunteer format. Based on presentations and discussions during the 14th ERGOMAS Conference in Athens, Greece, June 26-30, 2017, this special publication of Contemporary Military Challenges focuses on the challenges of recruiting and retaining interested young people in the armed forces.

In the ERGOMAS Working Group "Recruitment and Retention", 20 papers from different researchers were presented. In the five conference sessions on this issue, we had interesting discussions on various related topics. Session 1 dealt with the subject of minorities in the armed forces, and especially how they can be integrated and how they can participate in the system. In the next session, recruitment and retention in the reserve forces stood as the theme of the presentations. Politics and the military: mutual influence and the effect on military personnel was the topic of session 3 , and session 4 analyzed the motivational factors and reasons for attrition. The last session focused attention on recruitment and retention strategies. From these five sessions we were able to choose five presentations from all of these topics to adapt as journal articles. In the five articles offered in this journal, recruitment and retention are broadly discussed in historical terms and also based on the most recent research results.

In military sociology research has generally addressed the recruitment of volunteers into the active force, but the reserve components and the conscription system should also be reviewed in detail. This special issue also analyzes reserve forces and conscription systems with regard to recruitment and retention.

In the past not much attention has been paid to the topic of recruitment and retention in Europe. This was also true during the time of the Cold War for the conscript-based 
armed forces; the recruitment of new personnel was guaranteed by the conscript system. The advantages of this system were that the conscripted young men (in Europe only men were obliged to enter the armed forces; for women this was on a volunteer basis, and in some countries it was even forbidden for women to join the armed forces, or they could join only in auxiliary positions) could be socialized during their military service and also convinced that a professional military position could be a career for them. In other words, through the conscript system the armed forces were able to win new personnel who could imagine staying in the armed forces as long-term employees.

One consequence of this was that the armed forces did not have to recruit new personnel on the free job market. The 'in-house' recruiting system provided by conscription was in most cases sufficient to catch enough personnel and - very importantly - well-qualified staff. But with the end of the Cold War and new missions, armed forces had to cover new tasks. These new tasks also required, on the one hand, personnel who were able and willing to stay abroad for a longer time, and on the other hand, new skills to cope with the new circumstances in the missions abroad. With the conflicts in the 1990s such as the Gulf War, the Somali Civil War with the United Missions UNOSMO I and II, the Bosnian War and the Kosovo War with the involvement of NATO, Western European armed forces had huge problems sending qualified personnel to these crises. Paradoxically the European armed forces were at that time much bigger in the number of soldiers than they are today, but in almost every country it was forbidden to send conscripted soldiers on missions abroad. Therefore the situation was that after the end of the Cold War these armed forces were not fit for the new tasks.

Through the experience gained within these missions, a process of multinationalization and professionalization took place in the European armed forces. Multi-nationalization meant that it was more important for many states to join alliances, especially NATO. In a multi-national framework the aspect of greater interoperability between different armed forces was given heed. This led to more professional structures. This structural change is strongly reflected in the number of armed forces that have suspended conscription. In 1990, just four out of 26 European countries had an all-volunteer force, i.e. no conscription system. Today, most European states have switched to an all-volunteer format for their armed forces. This situation has altered the manning system. The flow of newly conscripted recruits disappeared, and personnel had to be found on the free market.

At the same time as the armed forces were changing from conscript-based mass armies to leaner all-volunteer forces, civil society was engaged in a process of changing values. Traditional values such as obedience, discipline, and subordination became less significant for young people, and values such as autonomy and selfdetermination were esteemed much more. Some reasons for this were urbanization, an increasing level of education, and greater differentiation and specialization in the working environment. This led to a discrepancy between civil values that focus 
on the individual, and military values, which refer to the group dimension. At the moment the consequences of this process can be seen in the difficulty recruiting military personnel in sufficient quantity and quality. Questions related to human resources have become existential for armed forces; not only filling positions in the armed forces, but also adapting them to the new missions in a multicultural environment requires the urgent efforts of human resources development. Attention is now directed towards widening the recruitment pool. Women and young people with a migrant background should complement the traditional recruitment profile of a young, white male. Or in other words, the new recruiting targets must be on an equal footing with the old traditional recruitment basis. With that in mind the European armed forces must alter their recruitment outlook so that they will be attractive to these new target groups. The papers and research presented in this journal may help to broaden the understanding of this new recruitment and retention process.

Have a good read! 